\title{
RUNX1 Gene Mutation
}

National Cancer Institute

\section{Source}

National Cancer Institute. RUNX1 Gene Mutation. NCI Thesaurus. Code C38362.

A change in the nucleotide sequence of the RUNX1 gene. 